\title{
DNA Maintenance
}

National Cancer Institute

\section{Source}

National Cancer Institute. DNA Maintenance. NCI Thesaurus. Code C18300.

DNA Maintenance involves cellular mechanisms that maintain DNA integ rity. In many organisms, maintenance of DNA integ rity requires not only faithful DNA replication, but also DNA repair and recombination. $(\mathrm{NCl})$ 